\title{
THERMAL AND X-RAY INVESTIGATIONS OF KOWAK CLAY IN NORTHWESTERN TANZANIA AND ITS POSSIBLE INDUSTRIAL USE
}

\author{
EHJ Lugwisha \\ Chemistry Department, University of Dar es Salaam \\ P.O. Box 35061, Dar es Salaam, Tanzania.
}

\begin{abstract}
A study of some properties of clays collected from selected sites in Kowak deposit in Tarime District was carried out in order to assess their suitability as raw materials in ceramic and its related industries. The silica $\left(\mathrm{SiO}_{2}\right)$ content in the clays is predominant, and is about $66.89 \%$ followed by alumina $\left(\mathrm{Al}_{2} \mathrm{O}_{3}\right)$ that is 20.2\%. Haematite $\left(\mathrm{Fe}_{2} \mathrm{O}_{3}\right)$ was found to be the third in abundance with an average of $3.58 \%$. Other constituents are present in small proportions. Water loss at $105^{\circ} \mathrm{C}$ lies between $2.70 \%$ and $2.76 \%$. DTG, TG, XRD techniques and chemical analyses studied by AAS method were used to determine the minerals present in the deposit. Two clay minerals, namely, illite and kaolinite were dominant. The non-clay minerals, referred to as "impurities" found in clays include quartz, pyrope and potash-feldspar $\left(\mathrm{K}_{2} \mathrm{O} . \mathrm{Al}_{2} \mathrm{O}_{3} .6 \mathrm{SiO}_{2}\right)$ in the form of microcline. Illite, kaolinite, quartz and potash-feldspar were found in all sites of the deposit while pyrope was revealed in one site only. On the basis of this study, the results obtained from the chemical, thermal and mineralogical analyses, suggest that the clays from the deposit could be exploited for the manufacture of bricks, tiles and some limited ceramic ware.
\end{abstract}

\section{INTRODUCTION}

An investigation of clay from Tarime District in northwestern Tanzania was carried out. The District is endowed with both large and small deposits of minerals in different locations. One of the known deposits "the Kowak deposit", where clays occur in significant amount was studied. The clay from this deposit is used locally for the manufacture of bricks, pottery and tiles (Koepel 1986). Hitherto no detailed scientific study has been carried out on the genesis of the deposit.

In the present study, DTA, TG and XRD techniques supplemented by chemical analysis have been employed to investigate the composition of the clays. The investigation was carried out in order to identify the main constituents of the clay samples and characterize the clay minerals for possible industrial applications.

\section{METHODS}

\section{Sampling}

Five samples taken from different sites in the Kowak deposit were studied in this investigation. They were coded as samples $\mathrm{S}_{1}, \mathrm{~S}_{2}, \mathrm{~S}_{3}, \mathrm{~S}_{4}$ and $\mathrm{S}_{5}$. The samples were collected at about $1 \mathrm{~m}$ and $3.5 \mathrm{~m}$ below the earth's surface and each sample was mixed thoroughly to obtain a homogenous mixture.

\section{Chemical analyses \\ Moisture content determination}

Each sample was finely ground and about 20 $\mathrm{g}$ of the less than 100 mesh portion was dried over night in an oven at $100^{\circ} \mathrm{C}-$ $105^{\circ} \mathrm{C}$. The difference in weight was used to calculate the percentage loss on drying. Duplicate determinations were carried out and averaged.

\section{Cation determination}

The procedure adopted in the determination of $\mathrm{SiO}_{2}$ content was different from that employed in the analysis of other cations. Ten grams of each clay sample was accurately weighed into a $150 \mathrm{ml}$ beaker. 50 $\mathrm{ml}$ of conc. Hydrochloric $(\mathrm{HCl})$ acid was added and placed on a steam bath for six hours with occasional stirring and topping up with conc. $\mathrm{HCl}$ acid to replace that lost 
by evaporation. After sixteen hours heating the final volume was allowed to decrease to $25 \mathrm{ml}$. The solution was then diluted to about $50 \mathrm{ml}$ with distilled water and the $\mathrm{SiO}_{2}$ filtered into a sintered crucible G4. The residue was then washed with distilled water and all the filtrate and washings were collected in $100 \mathrm{ml}$ graduated flask and reserved for the determination of metal composition while the $\mathrm{SiO}_{2}$ content in the crucible $\mathrm{G} 4$ was dried in an ovenover night at $120-150^{\circ} \mathrm{C}$. The crucible was reweighed and the difference in weight was used to determine the $\mathrm{SiO}_{2}$ content in the samples (Vogel 1984).

The elements $\mathrm{Al}, \mathrm{Ti}, \mathrm{Fe}, \mathrm{Ca}, \mathrm{Mg}, \mathrm{Na}, \mathrm{K}$, $\mathrm{Cr}, \mathrm{Mn}, \mathrm{Pb}, \mathrm{Zn}$ and $\mathrm{V}$ were determined by AAS method using Perkin-Elmer 2380. Each volume of standard stock solution prepared contained an equivalent of 1000 ppm of the respective element was diluted so as to give an absorbance within the linear range of the metal to be determined. A hollow cathode lamp of the element to be determined was selected, placed in its position in the spectrophotometer, properly aligned and lit. Each solution of unknown concentration was aspirated and directly read its concentration. Distilled water was aspirated for zeroing the instrument. The values obtained were multiplied with dilution factor to get the actual concentration of the original sample solution. Duplicate determinations for each metal was carried out and averaged. Nitrous oxide flame was used in atomic excitation of $\mathrm{Al}, \mathrm{Ti}$, and $\mathrm{V}$ in which a very high temperature is vital, while air-acetylene flame was used to the rest of the metals (Vogel 1984).

\section{Mineralogical analyses \\ Thermoanalytical techniques}

The differential thermal analyses (DTA) of clays were done by the Stanton-Redcroft model 673-4 with an attached digital volmeter connected to a PC. The temperature range for the measurement was from ambient temperature to $1000{ }^{\circ} \mathrm{C}$. The thermocouple utilised was Pt/Pt:13\% Rh. and the heating rate for all clays was maintained at $10^{\circ} \mathrm{C} /$ minute. Calcined alumina was used as the reference material and the specimen holder was platinum.

The thermogravimetric analyses (TG) were performed using the Stanton-Redcroft TG.750 with an attached digital voltmeter and a PC. The heating operation was done from ambient temperature to $1050{ }^{\circ} \mathrm{C}$ at the heating rate of $10{ }^{\circ} \mathrm{C}$ per minute.

\section{$X$-ray diffraction analysis (XRD)}

$\mathrm{X}$-ray diffraction patterns were recorded by the Siemens D-5005 X-ray Diffractometer. $\mathrm{CuK}_{\alpha}$ radiation $(\lambda=1.54056 \AA)$ was employed. The samples underwent diffraction in the measuring range $2 \theta$ ranging between $2^{\circ}-65^{\circ}$.

\section{RESULTS AND DISCUSSION \\ Chemical analysis}

The results of chemical analysis for the five samples $\left(\mathrm{S}_{1}, \mathrm{~S}_{2}, \mathrm{~S}_{3}, \mathrm{~S}_{4}\right.$, and $\left.\mathrm{S}_{5}\right)$ expressed in percentages, including percentage losses of water at $105^{\circ} \mathrm{C}$ are presented in Table 1.

There was a wide variation of chemical constituents. For all the samples alumina ranked second in abundance (ranges between 17.12 and $22.57 \%$ ) after silica ( $>63.81 \%$ ) followed by haematite while lead oxide, zinc oxide and chromate are the least in all the samples. However, $\mathrm{Fe}_{2} \mathrm{O}_{3}, \mathrm{MgO}$ and $\mathrm{K}_{2} \mathrm{O}$ occur in large proportions compared to other oxides (Table 1). It was observed that the amount of silica in clays is much higher and vice versa for alumina when compared to the theoretical values of pure kaolinite. Pure kaolinite has a theoretical chemical composition of $46.55 \mathrm{wt} \% \mathrm{SiO}_{2}, 39.49 \mathrm{wt}$ $\% \mathrm{Al}_{2} \mathrm{O}_{3}$ and $13.96 \mathrm{wt} \% \mathrm{H}_{2} \mathrm{O}$. However, in nature kaolinite is rarely found in pure form. Two types of impurities are associated with kaolinite: impurity resulting from isomorphous substitution of an element into the kaolinite structure and impurities resulting from accessory minerals that adhere to the surface area of kaolinite. The latter type can affect some intended use of a particular clay but this may be handled by 
diverse beneficiation techniques (Ekosse 2001, Kimambo 1988). The water contents obtained at $105^{\circ} \mathrm{C}$ were less for the clays investigated compared to those reported in the literature which was in the range between 7.77 and $11.37 \%$ (Kirk-Othmer 1979). This discrepancy may be ascribed to the regularity in units arrangement of clay minerals that cause small amounts of adsorbed water to be found between/or within layers, and secondly, the variation of grain size of the clay materials. Note that increase in particle size is accompanied by decrease in surface area, hence a small amount of adsorbed water is present in clay materials. However, this water is not very important, as it only depends on the humidity (wet or dry season). Loss on ignition at $600^{\circ} \mathrm{C}$ is crucial because it measures molecular water.

Table 1: Chemical composition (in \%) of clay minerals studied.

\begin{tabular}{lllllllll}
\hline Sample & $\mathrm{SiO}_{2}$ & $\mathrm{Al}_{2} \mathrm{O}_{3}$ & $\mathrm{TiO}_{2}$ & $\mathrm{Fe}_{2} \mathrm{O}_{3}$ & $\mathrm{CaO}$ & $\mathrm{MgO}$ & $\mathrm{Na}_{2} \mathrm{O}$ & $\mathrm{K}_{2} \mathrm{O}$ \\
\hline $\mathrm{S}_{1}$ & 70.01 & 17.12 & 0.10 & 3.63 & 0.34 & 0.41 & 0.03 & 0.50 \\
$\mathrm{~S}_{2}$ & 70.22 & 18.00 & 0.12 & 3.66 & 0.36 & 0.39 & 0.04 & 0.50 \\
$\mathrm{~S}_{3}$ & 64.01 & 22.29 & 0.11 & 3.46 & 0.38 & 0.37 & 0.03 & 0.48 \\
$\mathrm{~S}_{4}$ & 63.81 & 22.57 & 0.11 & 3.51 & 0.41 & 0.40 & 0.03 & 0.39 \\
$\mathrm{~S}_{5}$ & 66.42 & 21.02 & 0.12 & 3.63 & 0.98 & 0.35 & 0.03 & 0.46 \\
\hline Sample & $\mathrm{Cr}_{2} \mathrm{O}_{3}$ & $\mathrm{MnO}$ & $\mathrm{PbO}$ & $\mathrm{ZnO}$ & $\mathrm{V}_{2} \mathrm{O}_{5}$ & $\mathrm{H}_{2} \mathrm{O}$ & LOI & Total \\
\hline $\mathrm{S}_{1}$ & 0.007 & 0.04 & 0.0033 & 0.001 & 0.003 & 2.76 & 5.11 & 100.07 \\
$\mathrm{~S}_{2}$ & 0.923 & 0.04 & 0.0039 & 0.002 & 0.003 & 2.64 & 5.30 & 101.2 \\
$\mathrm{~S}_{3}$ & 0.0121 & 0.039 & 0.0031 & 0.005 & 0.003 & 2.67 & 5.56 & 99.90 \\
$\mathrm{~S}_{4}$ & 0.0141 & 0.04 & 0.0038 & 0.002 & 0.003 & 2.88 & 5.72 & 99.89 \\
$\mathrm{~S}_{5}$ & 0.0132 & 0.04 & 0.0035 & 0.002 & 0.003 & 2.70 & 4.22 & 99.99 \\
\hline
\end{tabular}

Table 2: $\quad$ Mineralogy of samples as determined by XRD. $M=$ major; $\mathrm{m}=$ minor, $\mathrm{T}=$ trace.

\begin{tabular}{llllll|}
\hline Sample & Quartz & Illite & Kaolinite & Microcline & Pyrope \\
\hline $\mathrm{S}_{1}$ & $\sqrt{ } \mathrm{M}$ & $\sqrt{ } \mathrm{M}$ & $\sqrt{\mathrm{m}}$ & $\sqrt{\mathrm{m}}$ & $\sqrt{ } \mathrm{m}$ \\
$\mathrm{S}_{2}$ & $\sqrt{ } \mathrm{M}$ & $\sqrt{ } \mathrm{M}$ & $\sqrt{ } \mathrm{m}$ & $\sqrt{\mathrm{m}}$ & \\
$\mathrm{S}_{3}$ & $\sqrt{ } \mathrm{M}$ & $\sqrt{ } \mathrm{m}$ & $\sqrt{\mathrm{m}}$ & $\sqrt{ } \mathrm{m}$ & \\
$\mathrm{S}_{4}$ & $\sqrt{ } \mathrm{M}$ & $\sqrt{ } \mathrm{m}$ & $\sqrt{\mathrm{m}}$ & $\sqrt{\mathrm{m}}$ & \\
$\mathrm{S}_{5}$ & $\sqrt{ } \mathrm{M}$ & $\sqrt{ } \mathrm{m}$ & $\sqrt{ } \mathrm{m}$ & $\sqrt{ } \mathrm{m}$ & \\
\hline
\end{tabular}

\section{X-ray Diffraction analysis}

X-ray results are given in Table 2. Quartz, illite, kaolinite and microcline [K-feldspar$\mathrm{KAlSi}_{3} \mathrm{O}_{8}$ ] are present in all samples. Among these, quartz and illite are seen to be predominant while the rest occur in minor quantities. However, for sample $\mathrm{S}_{1}$ pyrope [Mg-feldspar - $\left.\mathrm{Mg}_{3} \mathrm{Al}_{2}\left(\mathrm{SiO}_{4}\right)_{3}\right]$ was the only accessory mineral present. These results are in good agreement with both chemical and thermal analyses. The concentration values for silica which is of the average of $69.01 \%$ and aluminium $20.2 \%$ obtained by chemical analysis agree with quartz (major), kaolinite and illite (minor) contents in the samples. The data obtained by thermal analysis are discussed below; they also show the correlation with the mineralogical composition. The high percentages of $\mathrm{SiO}_{2}$ is a sign of quartz dominance in all samples.

\section{Thermoanalytical characterisation}

The differential thermal analysis (DTA) results are presented in Table 3. The thermogravimetry (TG) and differential thermogravimetry (DTG) curves labeled, (a) and (b), respectively, for each sample are plotted in the same Figure. Their thermograms are presented in Figs. 1 - 5 for samples $\mathrm{S}_{1}$ to $\mathrm{S}_{5}$, respectively. Both DTG and $T G$ curves of samples $S_{1}$ and $S_{2}$ largely resemble. The differential thermal analysis 
curves of $S_{1}$ and $S_{2}$ show broad endothermic peaks at $98^{\circ} \mathrm{C}$ and $92^{\circ} \mathrm{C}$, respectively, which are due to the loss of adsorbed water while dehydroxylation peaks occur at $484^{\circ} \mathrm{C}$ and $579^{\circ} \mathrm{C}\left(\mathrm{S}_{1}\right)$ and at $579^{\circ} \mathrm{C}, 688.5^{\circ} \mathrm{C}$ and $724.7^{\circ} \mathrm{C}\left(\mathrm{S}_{2}\right)$. Broad exothermic peaks which are results of the burning off of organic matter present in $\mathrm{S} 1$ appear at $260^{\circ} \mathrm{C}$ and $323^{\circ} \mathrm{C}$ while the endo/exothermic peaks appear between $854^{\circ} \mathrm{C}$ and $917.7^{\circ} \mathrm{C}$. The peaks observed indicate the presence of illite and quartz in these samples, observations which are supported by X-ray analysis. The thermogram curves of these samples given in Figs. 1 and 2 show two distinct features, namely, the abrupt weight losses, which occur in two stages in both samples and the gradual weight losses. The first stage for $\mathrm{S}_{1}$ occurs between $25^{\circ} \mathrm{C}$ and $194^{\circ} \mathrm{C}$ associated with broad weak endothermic peak at $98^{\circ} \mathrm{C}$ and accompanied with weight loss of $2.2 \%$ while for $\mathrm{S}_{2}$ it occurs between $25^{\circ} \mathrm{C}$ and $140^{\circ} \mathrm{C}$ associated with broad endothermic peak at $92^{\circ} \mathrm{C}$ and weight loss of about $1.5 \%$.
In the second stage, the weight loss for $\mathrm{S} 1$ and $\mathrm{S}_{2}$ of about $2.2 \%$ and $1.8 \%$, respectively, occurs between $440^{\circ} \mathrm{C}$ and $654^{\circ} \mathrm{C}$ for $\mathrm{S}_{1}$ and between $427^{\circ} \mathrm{C}$ and $684^{\circ} \mathrm{C}$ for $\mathrm{S}_{2}$ both associated with an endothermic peak at $579^{\circ} \mathrm{C}$. The reaction at these temperature ranges is due to the dehydroxylation of illite. The weight loss of about $0.6 \%$ which occurs between $654^{\circ} \mathrm{C}$ and $817^{\circ} \mathrm{C}$ for $\mathrm{S}_{1}$; and between $688.5^{\circ} \mathrm{C}$ and $724.7^{\circ} \mathrm{C}$ for $\mathrm{S}_{2}$ is due to the water bonded to magnesium in an octahedral position of dioctahedral illite (Grim 1968). The large sharp endo/exothermic peaks between $854^{\circ} \mathrm{C}$ and $917^{\circ} \mathrm{C}$ for $\mathrm{S}_{1}$ are not associated with any weight loss but they may be due to reorganisation and rearrangement of new phases of illite. For $\mathrm{S}_{2}$, a gradual weight loss which continues to $684^{\circ} \mathrm{C}$ is due to dehydroxylation of illite (Grim 1968). The XRD patterns of these samples confirm these observations.

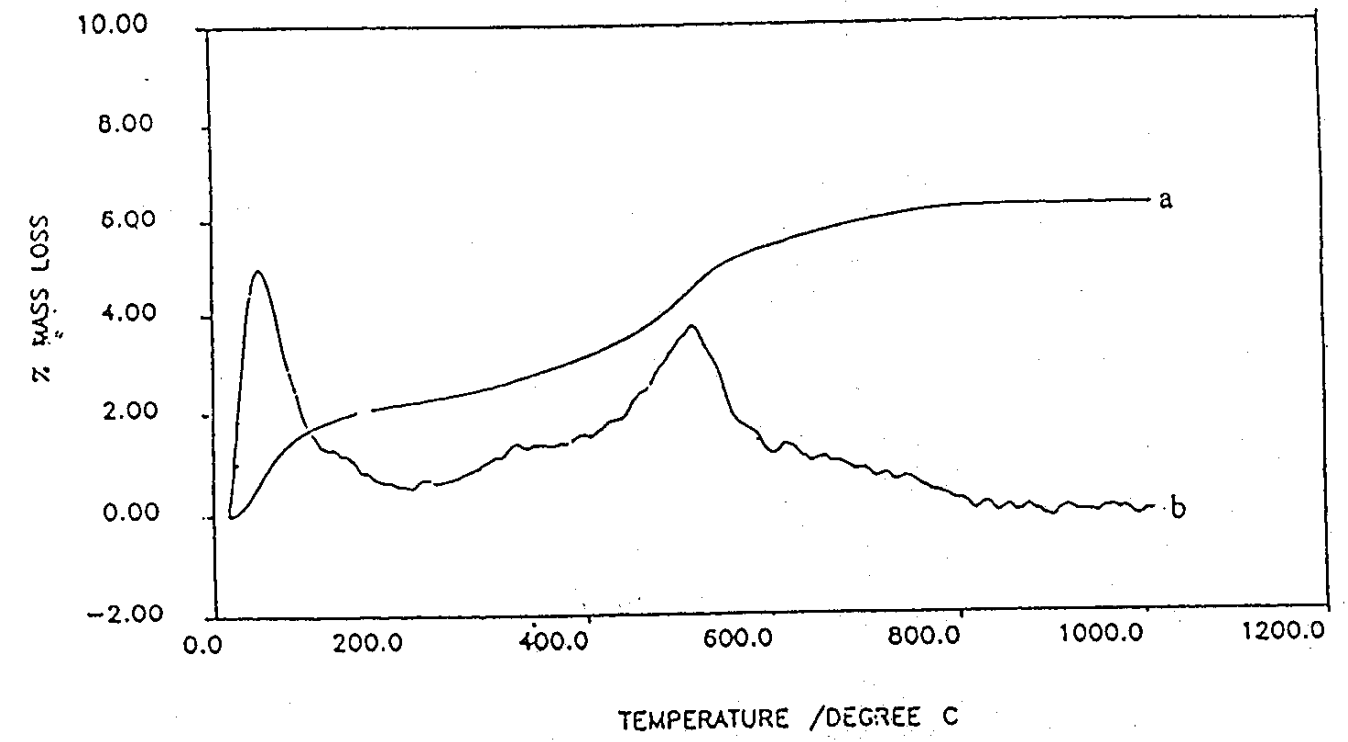

Figure 1: $\quad T G(a)$ and DTG(b) curves for sample $S_{1}$. 


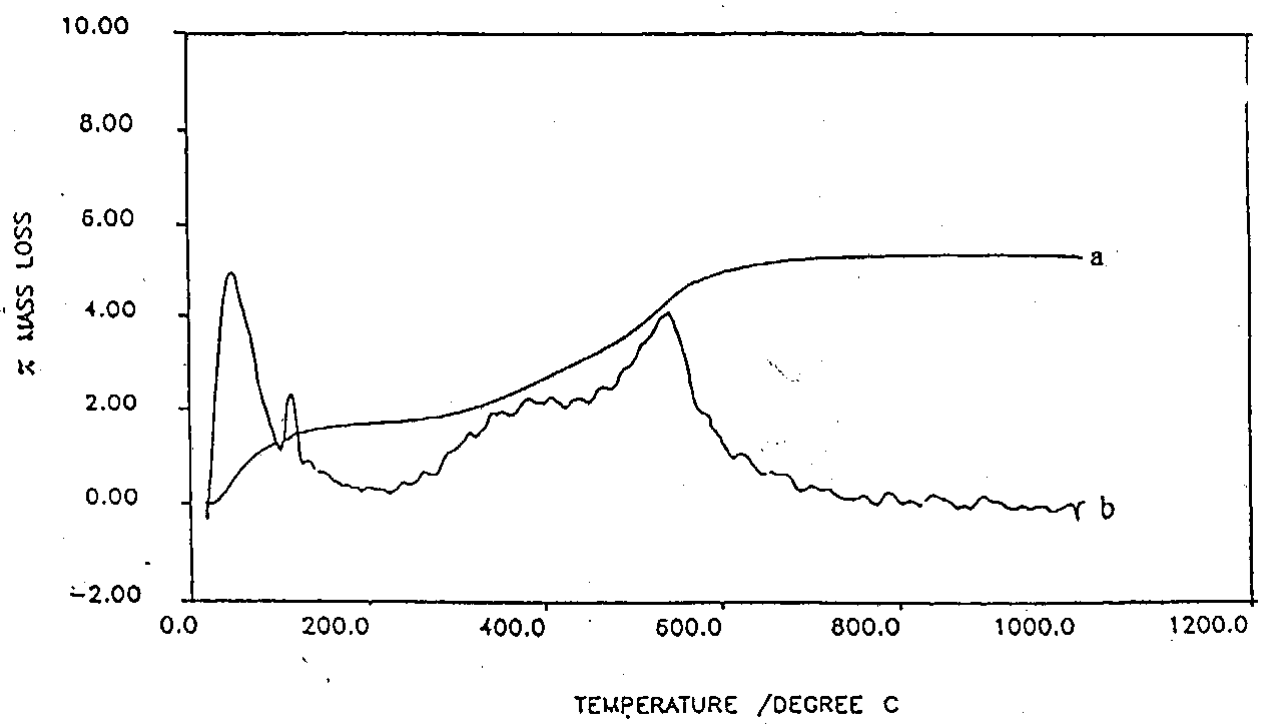

Figure 2: $\quad \mathrm{TG}(\mathrm{a})$ and $\mathrm{DTG}(\mathrm{b})$ curves for sample $\mathrm{S}_{2}$.

The differential thermal analysis results of $\mathrm{S}_{3}$ and $\mathrm{S}_{4}$ (Table 3 ) show broad weak endothermic peaks at $63^{\circ} \mathrm{C}$ and $60^{\circ} \mathrm{C}$ respectively; associated with the loss of free adsorbed water. This may be attributed to the presence of a crystallised kaolinite or dehydrated halloysite in the samples (Grim 1968). Allophane and hydrated halloysite are ruled out because they show well-developed peaks at around $100^{\circ} \mathrm{C}$ (Grim 1968). Small sharp peaks due to dehydroxylation of crystal lattice are observed at $578^{\circ} \mathrm{C}$. This is in good agreement with the reported value of $583^{\circ} \mathrm{C}$ for well crystallised kaolinite (Grim 1968 ), though it is slightly lower by ca. $0.8 \%$. The cause of this observation is likely to be due to small particle sizes of the samples. From the survey of clay minerals by Grim (1968) and Brindley (1961), it is concluded that dehydration temperature decreases with decreasing particle size. The main endo/exothermic peaks between $854^{\circ} \mathrm{C}$ and $908^{\circ} \mathrm{C} \quad\left(\mathrm{S}_{3}\right)$ and between $734^{\circ} \mathrm{C}$ and $788^{\circ} \mathrm{C}\left(\mathrm{S}_{4}\right)$ are more rounded than the well- crystallised kaolinite. According to Bentor et al. (1963) and Mackenzie (1970 a; b) all features are in agreement with the declared clay composition of kaolinite with some illite, results which are supported by XRD analysis. The thermograms of these two samples (Figs. 3 - 4) bear great similarity to one another; both show initial weight loss below $200^{\circ} \mathrm{C}(0.17 \%$ for S3 and $0.12 \%$ for $\mathrm{S}_{4}$ ). This is followed by a limited gradual weight loss up to $\approx 500^{\circ} \mathrm{C}$ (weight loss of ca. $0.42 \%$ and $0.03 \%$ for $\mathrm{S}_{3}$ and $\mathrm{S}_{4}$, respectively). Above this temperature, a rapid loss of lattice water (hydroxyls) takes place and terminates at $\sim 800^{\circ} \mathrm{C}$ for $\mathrm{S}_{4}$. The reaction taking place is due to dehydroxylation of illite. Sample $\mathrm{S}_{3}$ shows an extended gradual weight loss of endo/exothermic peaks between $854^{\circ} \mathrm{C}$ and $908^{\circ} \mathrm{C}$, which may be due to reorganisation and rearrangement of new phases of illite. These results are confirmed by X-ray analysis data. 


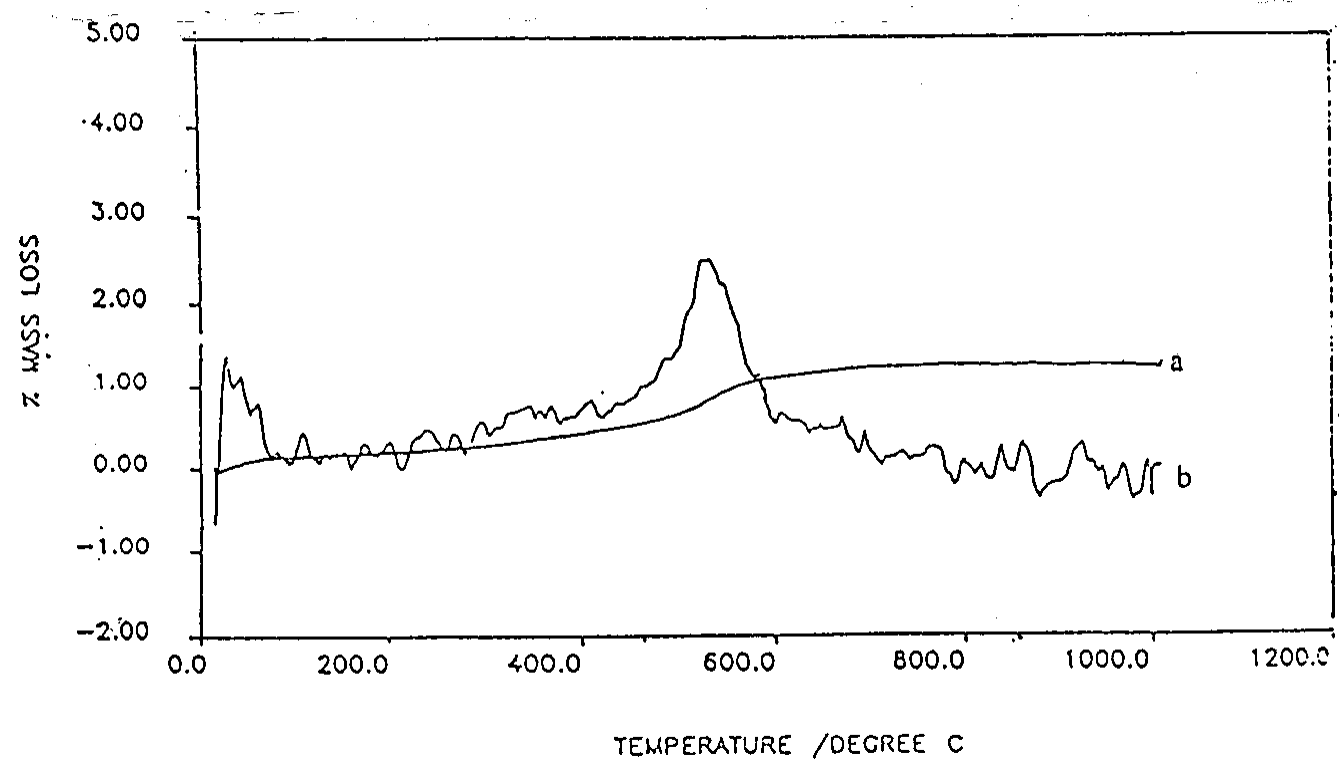

Figure 3: $\quad$ TG(a) and DTG(b) curves for sample $\mathrm{S}_{3}$.

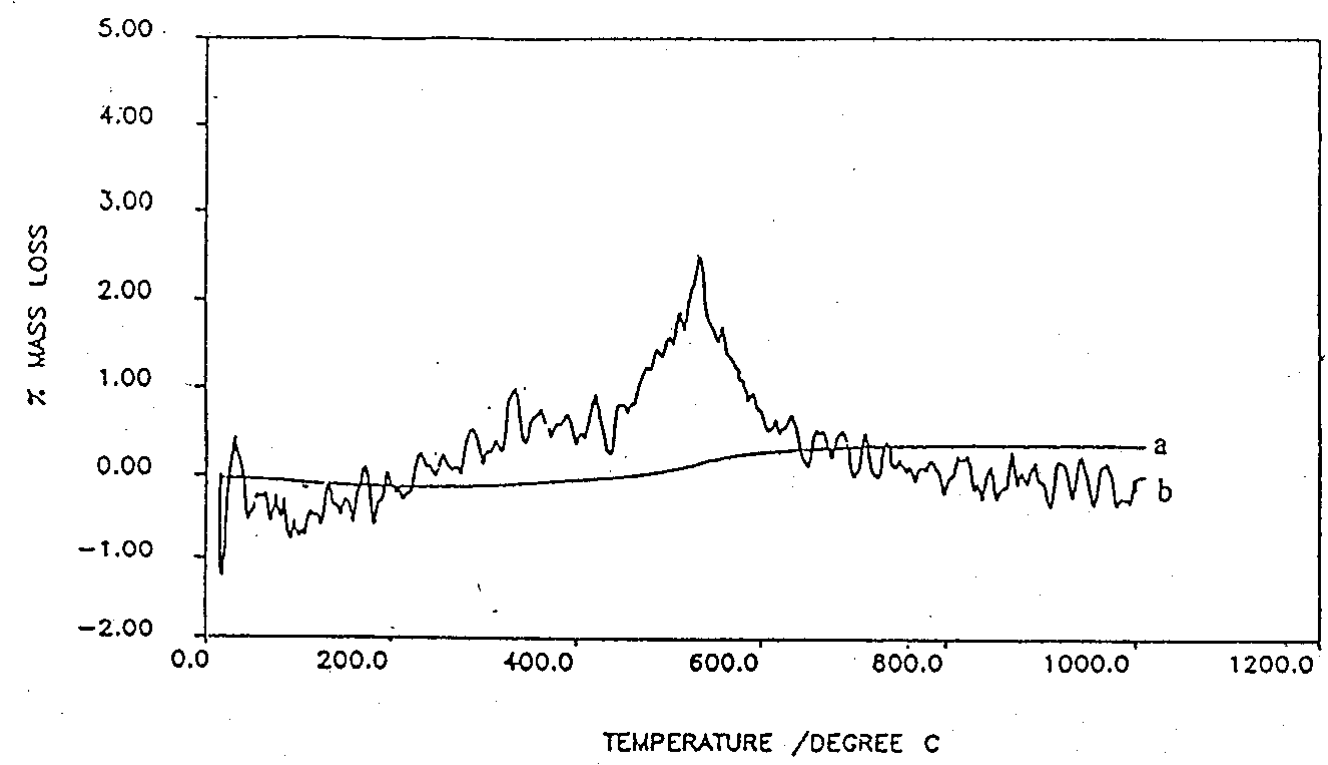

Figure 4: $\quad$ TG(a) and DTG(b) curves for sample $\mathrm{S}_{4}$.

The differential thermal analysis results of S5 (Table 3) show a broad weak endothermic peak at $88.6^{\circ} \mathrm{C}$, a small sharp endothermic peak at $738.6^{\circ} \mathrm{C}$ and a large sharp endo/exothermic peak with a shoulder (at $902.5^{\circ} \mathrm{C}$ ) occurring between $891^{\circ} \mathrm{C}$ and $959^{\circ} \mathrm{C}$. The only plausible interpretation for this observation would be the presence of 
two clay minerals - kaolinite and illite which take structural reorganization at different temperatures. These details are revealed in the TG curves and confirmed by XRD analysis. The thermogram curve of the sample (Fig. 5) shows abrupt weight loss of about $1.1 \%$ between $25^{\circ} \mathrm{C}$ and $161^{\circ} \mathrm{C}$. This weight loss is associated with a broad weak endothermic peak at $88.6^{\circ} \mathrm{C}$. Slight gradual weight loss of about $0.3 \%$ which occurs between $161^{\circ} \mathrm{C}$ and $290^{\circ} \mathrm{C}$ is associated with a loss of adsorbed water which is driven off with difficulty, while the other loss of about
$1.3 \%$ that occurs between $290^{\circ} \mathrm{C}$ and $471.5^{\circ} \mathrm{C}$ is due to burn off of organic matter present in this sample and lattice water belonging to kaolinite. Another abrupt weight loss of about $1.9 \%$ observed between $471.5^{\circ} \mathrm{C}$ and $743.7^{\circ} \mathrm{C}$ is due to dehydroxylation of kaolinie and illite. The weight losses are almost completed at $800^{\circ} \mathrm{C}$ with a corresponding endo/exothermic effect regarded to be due to illite clay transformations.

Table 3: $\quad$ DTA peaks of clay minerals

\begin{tabular}{|c|c|c|c|c|c|c|}
\hline & \multicolumn{2}{|c|}{ Endothermic peaks(maxima) } & \multicolumn{2}{|c|}{ Exothermic peaks(maxima) } & \multicolumn{2}{|c|}{ Endo/Exothermic peaks } \\
\hline & Temperature ${ }^{\circ} \mathrm{C}$ & Magnitude & Temperature ${ }^{\circ} \mathrm{C}$ & Magnitude & Temperature ${ }^{\circ} \mathrm{C}$ & Magnitude \\
\hline \multirow[t]{4}{*}{$\mathrm{S}_{1}$} & 98 & broad large & & & & \\
\hline & & & 260 & broad weak & & \\
\hline & 484 & broad weak & & & & \\
\hline & 579 & small sharp & & & $854-917.7$ & large and sharp \\
\hline \multirow[t]{4}{*}{$\overline{\mathrm{S}_{2}}$} & 92 & broad weak & & & & \\
\hline & 579 & small & & & & \\
\hline & 688.6 & large & & & & \\
\hline & 724.7 & large & & & & \\
\hline \multirow[t]{4}{*}{$\mathrm{S}_{3}$} & 63 & broad weak & & & & \\
\hline & 578 & Small sharp & 313 & broad weak & & \\
\hline & & & 785 & broad weak & & \\
\hline & & & & & $854-908$ & large and sharp \\
\hline \multirow[t]{4}{*}{$\mathrm{S}_{4}$} & 60 & broad weak & & & & \\
\hline & 578 & small sharp & & & & \\
\hline & & & & & $734-788$ & large \\
\hline & & & 907.6 & small sharp & & \\
\hline \multirow[t]{5}{*}{$\overline{\mathrm{S}_{5}}$} & 88.6 & broad weak & & & & \\
\hline & & & 430.4 & broad weak & & \\
\hline & & & 607.6 & large & & \\
\hline & 738.6 & small sharp & & & & \\
\hline & & & & & $891-959$ & large and sharp \\
\hline
\end{tabular}




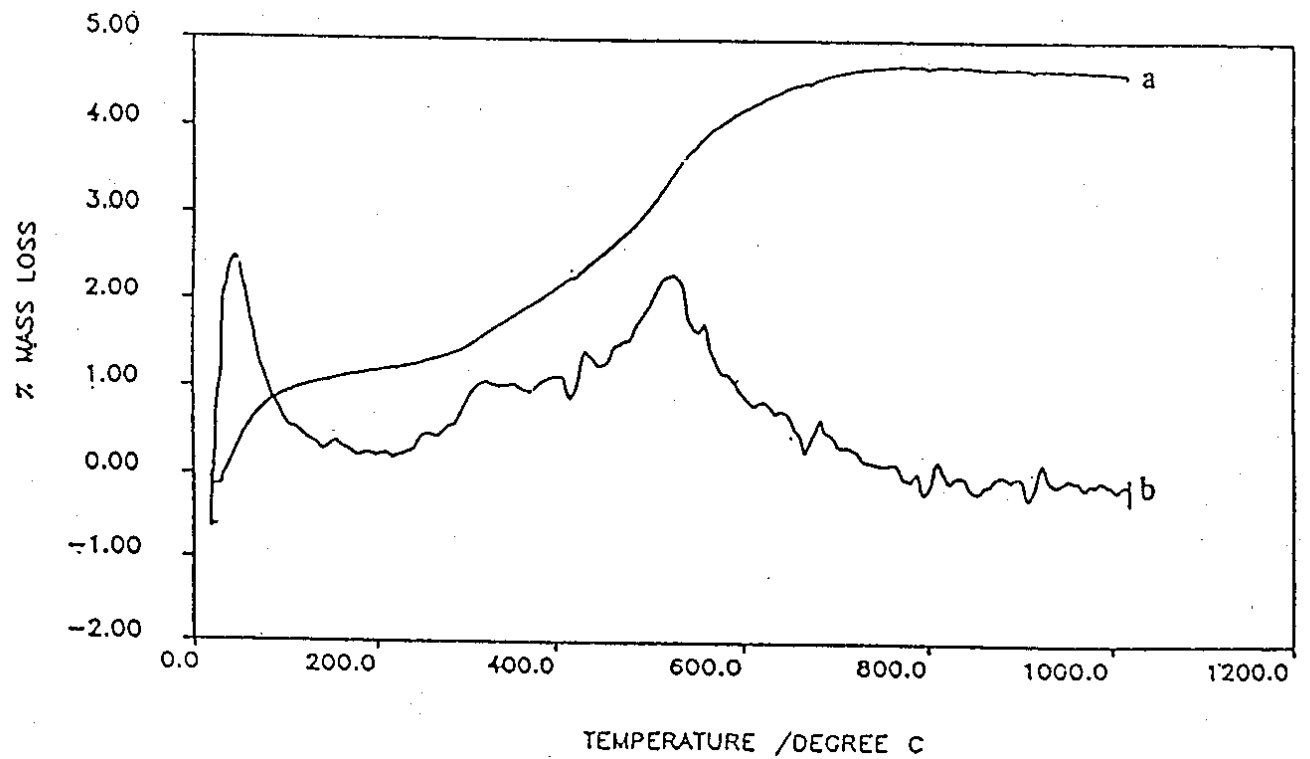

Figure 5: $\quad$ TG(a) and DTG(b) curves for sample $\mathrm{S}_{5}$.

\section{CONCLUSION}

The study has indicated that the chemical composition of the clay minerals present in the deposit is made up of mainly silica, with an average of $66.89 \%$, followed by the alumina, which is on the average of $20.2 \%$. Hematite is the third in abundance with an average of $3.58 \%$. Kaolinite and illite are the only clay minerals found in the deposit. Non-clay minerals found are quartz, pyrope and k-feldspar.

The clay minerals obtained are considered suitable in the manufacture of bricks and tiles. They could find other applications in ceramic industry. However, in order to optimize their properties for specific applications, they must be beneficiated accordingly. The colouring oxide, $\mathrm{Fe}_{2} \mathrm{O}_{3}$ which imparts the red pigmentation to the burned clay products is present in reasonable quantity, the amount in the clay samples ranges between $3.46 \%$ and $3.63 \%$. On this basis, therefore, making the raw materials from this deposit be suitable in the manufacture of certain types of colouring ceramic products. The low concentration of $\mathrm{Pb}$ in the deposit makes the kaolin to be used in both pharmaceutical and paper industries (Ekosse 2001). However, the high percentage of haematite rules out the application in paper industries and in the production of whiteware like porcelain due to the red colouring imparted by $\mathrm{Fe}_{2} \mathrm{O}_{3}$ unless the clay is beneficiated. The presence of silica in a large proportion (range between $25-50 \%$ ) is an advantage for use of raw materials in ceramic products, because of its ability in minimizing shrinkage on the drying and firing of ceramic products. Similarly, the absence of large proportions of organic matter is an added advantage for ceramic production.

This study has given preliminary results of the constituents of the deposit to ascertain some uses of these clays. Further investigations are underway to determine other properties such as plasticity, mechanical strength, particle size distribution, mineral structure etc in order to substantiate further the use of these clays in industries. 


\section{ACKNOWLEDGEMENT}

The research was funded by the Norwegian Agency for International Development (NORAD) and Gender Dimension Programme Committee (GDPC - University of Dar es Salaam) to whom the author is very grateful.

\section{REFERENCES}

Bentor YK, Bodenheimer W and Heller LA 1963 A Reconnaissance Survey of the Relationship between Clay Mineralogy and Geological Environment in the Negev (Southern Israel). J. Sed. Petrol. 33: 874.

Brindley GW 1961 The Kaolin Minerals Mineralogical Society, London.

Ekosse G 2001 Provenance of the Kgwakgwe kaolin deposit in Southeastern Botswana and its possible utilization. App. Clay Sci. 20:137-152

Grim RE 1968 Clay Mineralogy $2^{\text {nd }}$ Ed. McGraw-Hill, London.
Kimambo RH 1988 Development of the Non-Metallic Minerals and Silicate Industry in Tanzania, Vol II. Eastern Africa Publications Ltd., Arusha.

Kirk-Othmer 1979 Encyclopaedia of Chemical Technology, John Wiley \& Sons Inc., New York.

Koeppel W 1986 Compilation of raw material occurrences and their stability for building purposes. National Housing and Building Research Unit, Dar es Salaam.

Mackenzie RC 1970a Differential Thermal Analysis. Vol. 1: Fundamental Aspects, Academic Press, London.

Mackenzie RC 1970b Simple Phyllosilicates based on gibbsite and brucite-like sheets in Differential Thermal Analysis (R.C. Mackenzie, Ed.). Academic Press, London.

Vogels A 1984 Textbook of Quantitative Inorganic Analysis, $4^{\text {th }}$ Ed. Longman Inc., New York. 